\title{
The Integration of General Education in the Academic Programme to Enhance the Self-Efficacy of Accounting Students at a South African University
}

\author{
S.K. Naidoo \& S. Govender \\ Department of Management Accounting, Durban University of Technology, Durban \\ External Research Supervisor, Durban University of Technology, Kloof \\ naidoos@dut.ac.za,dr1govender@telkomsa.net
}

\begin{abstract}
The purpose of this paper is to investigate the impact of General Education in enhancing the Selfefficacy of Cost and Management Accounting (CMA) students to assess whether Self-efficacy, is having any positive influence on the students' academic performance. The research design for this paper was descriptive, longitudinal and a mixed-methods approach. The nature of the quasi-experimental approach that was used in the current paper is a non-equivalent pre-test and post-test control group design. The target population was CMA students. A census survey was conducted. Findings, which were analysed with the aid of descriptive statistics, indicate a significant correlation in the post-test (Self-efficacy) scores of the group that undertook the General Education Modules and not the group that did not undertake the General Education Modules. This paper recommends the implementation of General Education skills into the curriculum and a model to measure Self-efficacy of students. Moreover, these skills appear to be very poor amongst current learners and respondents believed that Self-efficacy could have a positive effect on the academic performance of learners.
\end{abstract}

Keywords: Management Accounting, Financial Accounting, General Education Skills, Critical Thinking Skills, Self-efficacy.

\section{Introduction}

Skills in General Education, including written communication, oral communication, critical thinking, quantitative analysis, science, information and computer literacy, amongst higher education learners are crucial for success at the tertiary levels in general and Accounting levels in particular. A low level of General Education skills affects the performance of learners and creates an obstacle for promotion prospects at the workplace. It usually affects their ability to learn and prosper in the workplace environment. De Villiers (2010: 17) emphasises the need for Accounting professionals and advisors to business, to possess both technical and soft skills, which include communication skills, in order for these individuals to be successful, effective and for continued growth of individual. The Department of Basic Education (2014) reports that between 2011 and 2013, the number of passes obtained by learners in Mathematics has increased. There was also a sharp drop in the pass rate in 2014. The percentage of those candidates who passed Mathematics at 40 percent increased from 30.1 percent to 40.5 percent between the years 2011 and 2013. There was also a decrease in the year 2014 to 35.1 percent for candidates who passed Mathematics at 40 percent. Moreover, the number of candidates writing Mathematics decreased from 241509 in 2013 to 225458 in 2014. The 5.4 percent drop in candidates who passed Mathematics at 40 percent and the declining number of 16051 learners writing Mathematics in 2014 remains a great concern.

Similar scenarios persisted in Mathematical Literacy. According to Taylor, Van der Berg and Mabogoane (2012), grade six language teachers did not perform well on the SACMEQ reading test. The National Education Evaluation and Development Unit (NEEDU) (2013) states that the most notable aspect identified is that 72 percent of the three best learners in each class studied were reading below the average grade two student level, and 22 percent were on or below the 'bad' norm. Ramos (2010: 31) points out that reading strategies and writing skills have a strong connection. The results indicated by NEEDU (2013) and Ramos (2010) show that reading strategies are valuable predictors of writing abilities. The Centre for Development and Enterprise (CDE) (2011) indicated that many existing teachers are not teaching well in Maths, Science, Commerce and Technology, and are poorly managed. Problems arise when a majority of these teachers are improperly trained. In one study, researchers found that of 73 matric Physical Science teachers from Dinaledi schools in South Africa (with extra Mathematics and Science resources) who were tested on basic problemsolving skills, only 60 percent were able to solve the problems (CDE 2011) over the last 20 years. Research has shown that South African teachers have insufficient awareness of the subject matter. Two sections of research thirteen years apart suggest that the problem has persisted. 
Carlsen (1999) suggests that teacher knowledge should consist of five main areas of knowledge namely, (i) General Education Context, (ii) Relevant Education Context, (iii) General Pedagogical Knowledge, (iv) Knowledge of Subject Matter and (v) Knowledge of Pedagogical Content. The studies indicate that most teachers lack knowledge in these key areas. These low levels of communication skills affect the academic performance of learners, not just in the field of Accounting, but also professionally. Communication skills also affect oral communication skills. Research confirms that Accounting professionals and lecturers believe that oral and written communication is pivotal for success in the Accounting profession. Wessels (2005) argues that professional accountancy bodies attach critical importance to communication and problem-solving skills. Newly appointed graduates with poor communication skills will lead to unproductive work, poor teamwork, inefficient control and eventually, failure in management. The question is due to different personal experiences and different educational styles. Gray (2010) points out that $91 \%$ of all Accounting professionals indicate that oral communication skills are important for new graduates and $74.5 \%$ indicate that new graduates rarely have the skills needed.

The Financial and Accounting Services Sector Education and Training Authority (FASSET) (2011) points out that the number of people needed in the occupational category regarding the financial sector is 78 percent for professionals, which includes Accounting and Auditing trainees and 13 percent of people required in the clerical and administrative fields. The South African Institute of Chartered Accountants (SAICA) (2008b) indicates that 24,444 students passed the Higher Grade version in 2006 for the Accounting Higher Grade subject. Furthermore, in higher education, graduates increased from 3,142 to 4,978 in 2006 for the first three-year degree. The number of new labour market entrants in 2006 was 5752, nearly a thousand more than the graduates generated in the same year, as highlighted by SAICA (2008b). SAICA points out that higher education does not generate enough graduates to meet the need for new entrants into the market. The demand at post-graduate level, based on the realistic scenario, shows that there would be a deficit of 35 percent in 2018, and if the economy were to grow at a higher rate, the deficit would be 65 percent in 2018 (SAICA 2008b). Clearly, from these figures, the supply is not in keeping with the demand in the South African labour market.

\section{The General Education Prerequisites of Professional Accounting Bodies}

The present section addresses the aspect of General Education skill requirements of accounting learners from the point of view of professional Accounting bodies. The study discusses the international education skill requirements standards as set out by the International Federation of Accountants (IFAC). The current section also reports on communication, technical and soft skills for accounting graduates to be successful and effective and for continued growth by professional bodies.

International Federation of Accountants: IFAC is a worldwide body for the Accounting profession, committed to serving the community interest by improving the disciple and assisting in the development of strong foreign economies. Deloitte Global Services (2019) highlight, that IFAC comprises more than 179 associates and has members in 130 countries and territories, comprising nearly 2.5 million accountants in public Accounting, education, government, business and trade.

Purpose and Scope of International Education Standards (IES): International Education Standards 3 recommends a mixture of skills that applicants need in order to be suitable as qualified Accountants, according to IFAC (2008a). IFAC (2008a) asserts that the objective of IES 3 is to ensure that applicants for affiliation to an IFAC member body are fully prepared with the correct mixture of skills, such as academic, personal, technical, interpersonal and organizational, to perform as proficient Accountants. Such skills would enable accountants to work as competent professionals in an ever more dynamic and challenging environment during their careers.

Fawcett (2015) believes that the soft skills and General Education skills that professional accountants require are the following:

- Intellectual skills (knowledge, understanding, analysis, application, synthesis and evaluation); 
- Technical and functional competencies (numeracy, measurement, reporting, decision making, compliance);

- Personal competencies (self-management, resourcefulness, prioritize, adapt, incorporate ethical values in decision-making, career scepticism);

- Interpersonal and communication competencies (work/communicate with others); and

- Organizational and business management skills (motivation, planning, leadership). According to IES 3 , the skills indicated above are important for persons on the lookout to becoming skilled accountants. IFAC (2008a) suggests that IES 3 similarly attempts to address non-business studies which encourage the development of both the prerequisite talents and may even be part of General Education learning. IES 3 does not include specialized Accounting learning, ethical standards, principles and behaviours, criteria for practical experience or professional competency evaluation.

Overview of IES 3: Talents constitute a part of a set of skills needed by competent accountants to display professionalism. IFAC (2008a) notes that competencies consist of expertise, talents, specialized standards, ethics and attitudes, and that competences are an example of future capabilities that can be applied through various surroundings. It would be important to ensure that technical Accounting training programs incorporate the above capabilities. The increased preference of employers, stakeholders and persons regarding qualified accountants who contribute to the workplace and to society have typically triggered a greater focus on professional expertise. IFAC (2008a) indicates that the qualifications requirements enable eligible accountants to effectively leverage the information acquired from General Education. IFAC further emphasises that criteria for skills requirements are not obtained from individual courses dedicated to them, but from the cumulative impact of specialized Accounting training, programming and experience in the field, developed further through lifelong personal learning. IES 3 classifies the skills as: (I) Intellectual; (II) Technological and Functional; (III) Personal; (IV) Interpersonal and Communication. (V) Skills in Organizational and Business Management (IFAC 2008b).

According to IES 3, the acquisition of the aforementioned skills is crucial for learners owing to be specialized accountants. In addition, the above-mentioned skills will give qualified accountants a competitive edge in the market place, according to IFAC (2008b), and are useful throughout the career of the accountant. However, IFAC (2008b) adds that at the point of qualification, not all of those skills will be completely developed. Many of these skills may be the subject of the continued growth of the profession. While not an end in itself, a strong base in General Education is one way of helping people become wide and diverse-minded individuals who can understand and interact effectively and who has the framework for conducting investigations, carrying out rational thought and performing critical evaluation (IFAC 2008b). IFAC (2008b) highlights that the foundation would allow candidates to take decisions in a broader sense of society; employ sound judgement and professional skills; help connect with different groups of people; encourage them to think collectively; and start the cycle of professional development.

International Skills Requirements of Accountants: As indicated by IES 3 in an earlier paragraph, learners in search of becoming specialized accountants ought to equip themselves with the following:

- Intellectual;

- Technical and functional;

- Personal;

- Interpersonal and communication; and

- Organizational and corporate management talents and General Education requirements.

Intellectual Skills: Bloom's Taxonomy (1956) highlights that intellectual talents are often distributed into six levels, as indicated in the section titled 'Models and Theories Section on Quality of Learning'. Up to that time, professional accountants' position may well have been limited to the collection of data used by everyone but, nowadays, qualified accountants also form the backbone of the judgment-making team. The six stages are Information, Comprehension, Implementation, Analysis, Synthesis (combining knowledge from a number of areas, predicting and drawing conclusions) and Evaluation. IFAC also reaffirms the skills. IFAC (2008b) is of the opinion that the analytical skills needed should include: 
- The aptitude to find, collect, organize and understand evidence from human, print and electronic sources; aptitude to locate, acquire, organize and understand information from human, print and electronic sources;

- The aptitude to analyse; study; logical and critical thinking; rational and critical analysis ability for analysis;

- The aptitude to ascertain and solve unstructured complications that may be in unfamiliar surroundings. According to IES 3 the above-mentioned intellectual talents enable professional accountants to resolve issues, make sound decisions and implement good judgment in difficult organizational circumstances (IFAC 2008b). These intellectual skills often form part of broad General Education.

Technical and Functional Skills: Technical and organizational skills are composed of general competencies as well as Accounting skills. According to IFAC (2008b), the skills take account of:

- Numeracy and IT aptitude;

- Decision modelling and risk analysis;

- Measurement;

- Reporting; and

- Conformity regarding regulatory and legislative standards.

Personal Skills: According to SAICA (2010), personal skills include the following:

- Fully independent management;

- Self-learning, motivation and initiative;

- Resource allocation (within time limits); and

- Customizability. IES 3 notes that personal competencies are associated to qualified accountants' attitudes and behaviour (IFAC 2008b). Personal competence growth can assist with independent learning and personal advancement.

Interpersonal and Communication Skills: SAICA (2010) suggests that interactive and communication talent includes the aptitude to:

- Collaborate with people/conflict resolution;

- Diversity issues;

- Dealing with appropriate results;

- Teamwork;

- Exhibition of points of view; and

- Effectively pay attention and read. IES 3 notes that interpersonal and communication expertise enable qualified accountants to collaborate with individuals for the organization's mutual interest; obtain and communicate information; shape sound judgments; and make efficient decisions (IFAC 2008b).

Organizational and Business Management Skills: SAICA (2010) highlights that the components of organizational and business management expertise include:

- Planning, project management and people management;

- Delegation;

- Coaching and mentoring;

- Leadership; and

- Broad business outlook/political awareness/global perspective. IES 3 proscribes that skills in institutional and corporate management are becoming progressively essential to skilled accountants who are being requested to play a more pivotal role in the everyday management of companies (IFAC 2008b). Accordingly, IES 3 suggests that it is necessary for qualified accountants to comprehend all facets of how a company works and they must therefore develop a broad market view, political understanding and a global perspective (IFAC 2008b). 
General Education Requirements: IFAC (2008b) claims that every specialized education curriculum should take account of a certain percentage of General Education and that this comprehensive General Education will make a significant contribution to the development of professional competences. General Education necessities vary significantly with each programme and with each country. IES 3 prescribes that General Education will focus on developing non-professional knowledge, intellectual expertise, personal expertise, interpersonal and communication expertise and management and organizational expertise. IFAC (2008b) claims that General Education will encourage lifetime education and provide groundwork for technical and accounting studies to draw on. IES 3 notes that the following may include General Education:

- Considering the movement of thoughts and activities in the past, the diverse traditions of the contemporary world, as well as a foreign outlook;

- Fundamental human behaviour awareness;

- Common sense of the world's wide range of ideas, problems and cultural, political and social forces;

- Experience of descriptive data analysis and assessment;

- Capacity to analyse and perform critical thought;

- Enable critical thinking;

- Admiration of art, literature and science;

- Knowledge of personal and social beliefs and investigation and decision practice; and

- Knowledge of making important judgments (IFAC 2008b).

General Education can come into being through a wide variety of ways and in various conditions. IES 3 stipulates that General Education, namely accounting, financial and specific skills; corporate and business expertise; and information technology awareness can be undertaken at any point in a degree program with a combination of the qualified Accounting topics curriculum (IFAC 2008b). IES 2, in the section 'Content of Professional Accounting Education Programs', also details the aspect of General Education. IFAC (2008b) states in IES 3 that General Education can also be entirely incorporated into accounting degree curricula, allowing for the development of strategic expertise all the way through the curriculum.

Accounting Professional's Skill Requirements: Research findings confirm what Accounting professionals and lecturers have been highlighting for a long time that beyond being good with figures, learners also need oral and written communication skills to be successful in the Accounting environment. Wessels (2005) believes that communication and problem-solving expertise are fundamental and are an important requirement by professional Accounting bodies. De Villiers (2010) also highlights the need for communication, technical and soft skills for accounting graduates to be successful and effective and for continued growth in the Accounting profession. Gray (2010) highlights that 91 percent of all Accounting specialists believe that oral communication skills are indispensable in newly qualified graduates and 74.5 percent believe that newly qualified graduates seldom had the required skills.

Newly employed graduates with inadequate communication talents can lead to inefficient workforce, ineffectual control, bad teamwork and therefore a breakdown in management. The issue with weak communication skills comes from diverse personal experiences and various educational styles. Kerby and Romine (2009: 176) point out that Accounting business professional must possess strong oral communication skills and that members of the educational faculty agree that these skills play a significant role in the Accounting Programme. Interpersonal skills, for instance communication, are also vital requirements for South African trainee accountants (Barac 2009). Baker and McGregor (2000) in their study using conjoint analysis in assessing significant characteristics of accounting learners found that one of the most important factors employers expect from new graduates is communication skills.

Models and Theories on Education Skills: The models and theories under discussion in the present section are essential regarding the independent variable of the study in relation to the General Education aspect of learners within tertiary institutions. Accounting in particular is primarily quantitative by nature. However, Management accounting, even though a sub-division of this large information, is qualitative in essence. The Chartered Institute of Management Accountants (CIMA) further supports the qualitative aspect of Management Accounting. CIMA defines Management Accounting as "the process of identification, measurement, accumulation, analysis, preparation, interpretation and communication of information (both 
financial and operating) used by management to plan, evaluate and control within an entity and to assure appropriate use of and accountability for its resources" (CIMA 2010). Data analysis, reporting and decisionmaking are fundamental aspects to the subject of Management Accounting.

The Management Accounting programme requires competencies like problem-solving, analysis and decisionmaking. Therefore, learners should have good communication skills and be proficient in reading, interpreting and analysing questions. The superficial approach presently used by many learners for studying may not be adequate in studying the programme of Management Accounting. Learners can be successful and achieve good results in Management Accounting through quality learning. Moreover, learners can achieve sound communication expertise and a deep approach to learning through quality learning (Pickworth 2001). Quality learning incorporates factors such as critical thinking skills, decision-making abilities, Rauding Theory and Bloom's Taxonomy. The Rauding Theory and Bloom's Taxonomy indicate the skills essential for quality of learning for learners to be successful in their studies.

Critical Thinking Skills: Critical thinking consists of a logically well-organized system that involves the application of an amalgamation of aptitudes. Kurland (2000) highlights that the abilities may include the use of the following essential skills:

Rationality: Rational thinking involves thinking with reason, consistency and logic and providing reasons or logic behind every thought or idea. It provides an objective way of thinking and an analytical approach to problem-solving and decision-making.

Self-Awareness: Self-awareness skill involves and requires the learner to think consciously and attentively. It also requires the learner to be alert and mindful. Self-awareness is about weighing the influences of motives and bias and recognising one's own assumptions or point of view.

Discipline: The process involves applying self-control and restraint. It is a meticulous, precise and comprehensive means of thinking. Discipline avoids impulsive judgement and provides resistance to manipulation.

Judgment: Judgement requires the learner to use opinion, reasoning and assessment in thinking. Judgement also involves recognising the significance of alternative assumptions and perspectives. As Kurland (2000) indicates above, the abilities needed for critical thinking were further supported by a panel of forty-six experts that included both men and women from throughout the United States and Canada (Facione, 2015).

Decision-Making and Problem-Solving Skills: The Knowledge Creation Model as illustrated in Figure 1 best explains the process of decision-making. Problem-solving abilities are also part of critical thinking skills and are essential aspects for studying Management Accounting owing to the structure of the programme's curriculum. Problem-solving often involves decision-making and decision-making is part of the Management Accounting curriculum. Problem-solving and decision-making are linked to each, requiring vision in identifying and developing options. 


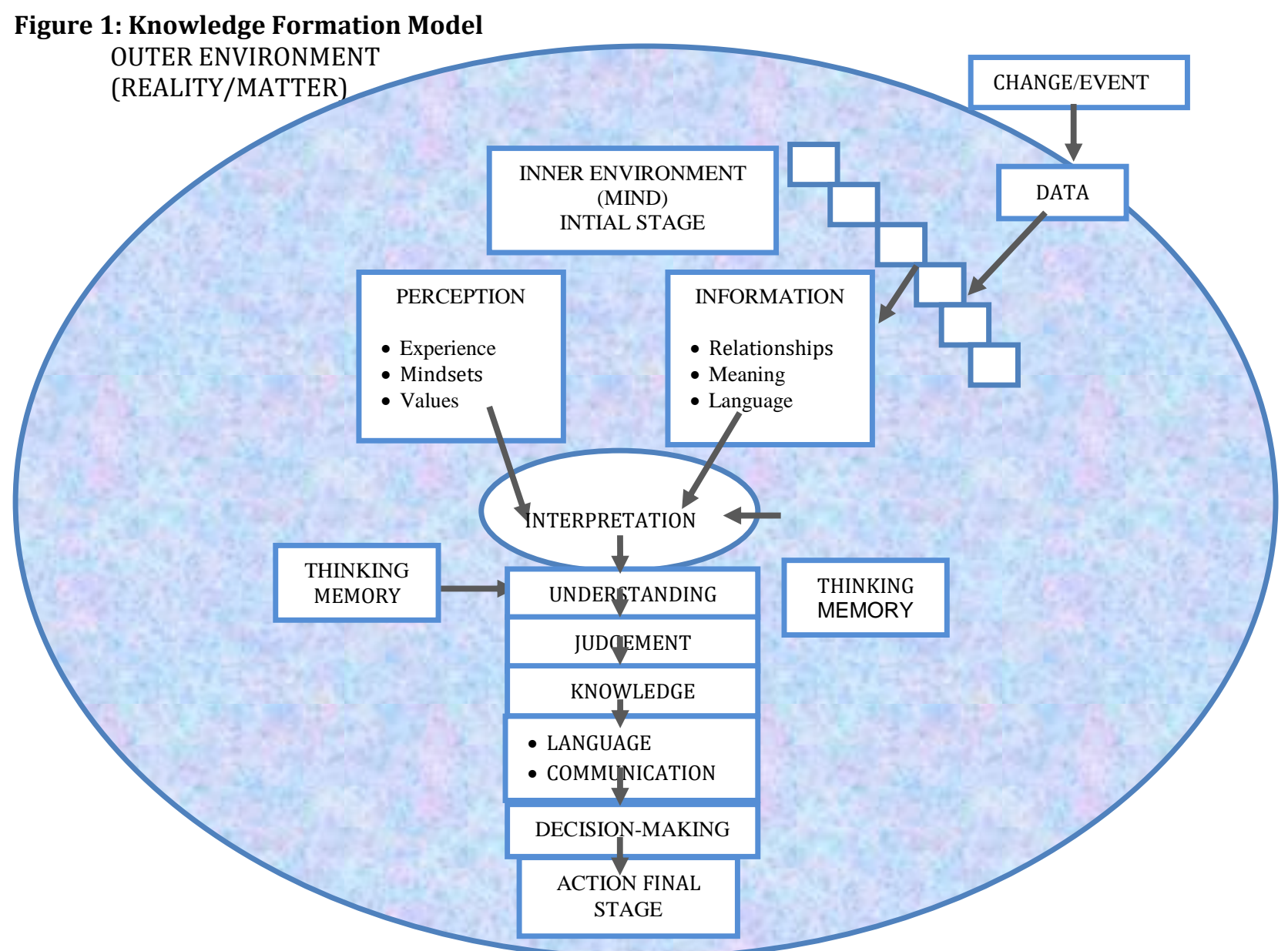

Source: Slabbert and Gouws (2006). Adapted.

Thinking memory decodes the information obtained via associations, meaning, language and perceptions acquired through experience, mind-sets and beliefs. Subsequent to interpretation and understanding of the data, a judgement is formulated, which influences knowledge. It is through language and communication that decision-making takes place, and action taken.

The Rauding Theory: The purpose of trying to read will be to grasp the substance of whatever the instructor or the problem demands, as well as to implement that information to eliminate the problem. Learners can engage various reading strategies when studying. The Rauding Theory best illustrates these reading approaches. Reading could be categorised as Scanning; Skimming; Rauding; Learning and Memorizing, according to the Rauding Principle (Carver, 1978). Rauding necessitates knowing or understanding a text, terms or sentences (Carver Learning Systems 2019). It is a mixture of reading and listening; reading by viewing written words to ascertain the context; and listening to spoken words to establish the meaning (Carver Learning Systems 2019). Especially in the science disciplines, learners will have to be able to read aggressively in order to answer essential questions, which can be accomplished through the means of the Rauding Theory. The Rauding Theory is also an appropriate method when studying the subject of Management Accounting. The common rapid and scanning methods used by learners may be more useful for reading newspaper articles (Carver, 1978). The Management Accounting programme requires learners to be proficient in reading in order to understand what is required from the question. Moreover, to be proficient, it is essential for them to acquaint themselves with the necessary skills.

Bloom's and Krathwohl's Taxonomies: The taxonomies in Figure 2 best illustrate the essential skills required for quality learning. The revised taxonomy is based on two aspects: firstly, to promote the retention of information and secondly, to transfer knowledge (Mayer, 2002). According to Mayer and Wittrock (1996 
cited in Mayer, 2002), retention is the ability to maintain knowledge at a future point, whereas transition is the ability to perform that which has been acquired to solve complex problems in completely different contexts. Remembering (level one) is connected with that of the retention of knowledge from the six stages defined in the revised taxonomy shown in Figure 2, while subsequent stages of comprehension, implementation, review, assessment and development are associated with information transfer (Mayer 2002). Black and Ellis (2010 cited in Thomas 2011) emphasise that the need for learners to always be able to function at all taxonomy levels.

Figure 2: Bloom's Taxonomy (Revised)

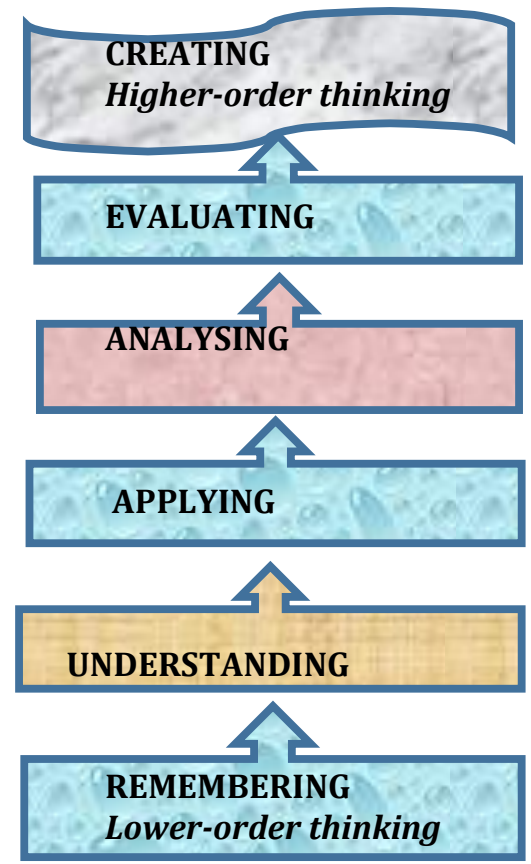

Source: Krathwohl's Taxonomy (2002). Adapted.

Self-Efficacy: This section discusses the idea of Self-efficacy, as extended to the academic programme for Accounting learners, particularly individuals who are experiencing problems academically. The emphasis will be on the dependent variable of Self-efficacy in learners. The concern is why some learners demonstrate higher degrees of self-confidence in their aptitudes, while others seem less confident of themselves. The answer to the difference between these two extremes could be attributable to the Self-efficacy of a student's belief in his or her capacity to perform tasks. There is a growing body of research revealing an optimistic noteworthy connection between Self-efficacy beliefs and academic performance. The current chapter charts the focal enhancements, the most crucial and continuing features and claims of Self-efficacy in understanding and using the concept in a knowledgeable way.

Self-Efficacy Role: Nearly everybody can decide on objectives that they would like to achieve, aspects they would really like to improve upon and things they would really like to accomplish. Nevertheless, most people do know that it is not as easy as people think to initiate such schemes into effect. Bandura and several others investigated and found that the Self-efficacy of a person plays a critical role in the way to manage goals, tasks and challenges. Bandura and others have researched and found that an individual's Self-efficacy plays a key role as to how to manage goals, tasks and challenges. Cherry (2018) highlights that those learners who have a robust awareness of Self-efficacy:

- Vision thought-provoking difficulties as responsibilities to be grasped;

- Mature a deep sense of attention in the actions in which they take part;

- Develop a deeper understanding of their desires and behaviours; and

- Make progress speedily from hindrances and displeasures. 
Cherry (2018) also believes that those learners with a fragile common sense of Self-efficacy:

- Evade thought-provoking errands;

- Assume that problem activities and circumstances are beyond their ability;

- Concentrate on moral weaknesses and negative consequences; and

- Extremely quickly run the risk of losing trust in personal skills. In addition, learners with elevated Self-efficacy tend to absorb and gain beyond persons with little Self-efficacy, even whilst the real skill rates are alike (Ormrod, 2008). The next section explains the sources of Self-efficacy.

Self-Efficacy Sources: In attempting to increase the Self-efficacy of learners, it is firstly important to identify and understand its sources. Cherry (2018) suggests that early childhood Self-efficacy continues to grow as youngsters cope with an extensive range of encounters, activities and circumstances. Nevertheless, Selfefficacy improvement did not necessarily conclude throughout early phases, but continues to expand throughout entire lives as people gain new talents, interactions and the ability to understand (Cherry, 2018). The sources of Self-efficacy stem from the learner's variety of experiences throughout their life. The primary research focus of Bandura's early work was on the tendency and ability of learners to understand and adjust their actions by vicarious interaction and social modelling, instead of by actual experience. Bandura (1994) advocates that Self-efficacy beliefs are formed according to how people perceive the feedback they receive from four sources: Past Performance (Bandura claims that one of the most powerful ways to build a clear sense of success would be through interactions of mastery);

- Modelled Behaviour;

- Social Persuasion or Feedback from others; and

- Physiological Responses.

Mastery Experiences: Zimmerman (2000) highlights that mastery experiences are in actual fact the most influential sources of efficacy belief for the purpose that they are produced from the outcomes of personal experiences. Mastery experience is a process whereby the learners actively engage in a task to obtain mastery over it (Bandura, 1994). If the level of task is too low or too high, then the efficacy levels can decrease (Bandura, 1994). Effectively and efficiently executing a task enhances a feeling of Self-efficacy for the learner. Failure to cope effectively with a mission or obstacle can thus compromise and severely damage the Selfefficacy of the learner (Bandura, 1994). This seems to have immediate consequences for education and training as regards the need to provide learners chances to acquire hard skills, as well as to have chances to show and encounter it as one aspect of the 'mastery' to build their personal feeling of Self-efficacy.

Modelling/Vicarious Experiences: Learners gain a great deal of knowledge concerning their abilities from learning how everyone else works. As Bandura (1977) points out, by examining others, learners acquire behaviours and then emulate or model what they have observed; develop the features of modelled behaviour; recognise the actions they wish to model; repeat those behaviours; and have the motivation/incentive to replicate such behaviours in the future. Classroom models such as teachers and peers are important sources of vicarious efficacy information. By way of observation, someone else who executes a challenging task can significantly influence Self-efficacy focusing on the source as well as the effectiveness of the participant (Bandura, 1994). Highly skilled models communicate information in addition to providing observers' valuable skills and techniques for meeting environmental challenges through all the actions and articulated ways of doing things (Bandura, 1994).

On the other hand, perceived failures could very well undermine the sense of success of learners and may actually prevent the learner from focusing on the assignment. The ensuing personal encounters repeatedly show these vicarious effects to be fraudulent. Zimmerman (2000) argues that if a model is deemed talented, then observers will underestimate for themselves the importance of the success outcomes of the model. McLeod (2014) performed a laboratory experiment similar to Bandura's 1961 experiment on bobo dolls, in which the independent variable occurred under three environments:

- Belligerent model displayed to 24 children;

- Non-aggressive model exposed to 24 children; and 
- No model presented (control condition) - 24 children. The results support the theory of social learning developed by Bandura (1977) that through observing other people's behaviours, children learn social behaviours such as violence through observation learning (McLeod, 2014).

Social/Verbal Persuasion: Social or verbal encouragement boosts the confidence of learners that they already have what is required to succeed. Bandura highlights that by reducing the self-doubts of learners, their attention on personal deficiencies will be halted by verbal persuasion. Learners may be encouraged to consider that they have both the skills and expertise to achieve. Persuasive changes in perceived Self-efficacy drive learners to strive further to achieve and encourages skills growth as well as a sense of self-effectiveness (Bandura, 1994). However, social persuasion has a minimal effect on students' Self-efficacy since outcomes are described, not independently verified, and thus rely on the integrity of the persuader (Zimmerman 2000). Therefore, there is a need for constructive strengthening of different skills along with learning, in addition to some motivation to perform the tasks. If learners are confident that they have the potential to succeed, then they should put in more resources than if they possess self-doubts as well as focus on personal failures when problems occur.

Psychological States: Emotions and feelings eventually affect learners and Bandura informs that learners will also depend on their responsive states to consider their competences. The learner's individual reactions and responsive feedbacks to circumstances also play a strategic role in Self-efficacy. According to Bandura (1994), the moods of learners, emotional reactions, physical responses and levels of stress can all influence how a person thinks about his or her personal attributes in a particular circumstance. In these circumstances, a person who becomes very nervous before speaking publicly can cultivate a poor sense of Self-efficacy. Bandura (1994) indicates, 'It is not the sheer intensity of emotional and physical reactions that is important, but rather how they are perceived and interpreted'.

Self-Efficacy Dimensions: Self-efficacy judgments vary on three individual but interconnected dimensions. The measurement of Self-efficacy relates to these interrelated dimensions. The dimensions referred to are magnitude, strength and generalizability. Subsequent to highlighting the three dimensions and the measurement of Self-efficacy, the section will focus on how these three-dimensional principles affect and relate to Management Accounting.

Magnitude: Firstly, the strength of one's expectations of effectiveness may explain the degree of task complexity that an individual believes is achievable (Bandura, 1977). Learners with an elevated degree of Self-efficacy will see themselves competent to accomplish difficult tasks whereas learners with a lower degree of Self-efficacy will see themselves as being merely capable of completing modest tasks.

Strength: Secondly, Self-efficacy expectancies fluctuate in their intensity (Bandura, 1977). Low expectancies are without difficulty extinguished by disconfirming information, while high expectations exist given such information (Brief and Aldag, 1981).

Generalisability: Thirdly, Self-efficacy anticipations vary in the level of their attainable generalisability (Bandura, 1977). Many learners may think they are qualified to carry out certain actions under a given set of conditions, whereas others may think they can carry out specific actions under any condition and take an action that is to some extent different. Albert Bandura's three dimensions of Self-efficacy theory within the Accounting environment is included below. The research paper will now focus on the three dimension pointed out above as applied and essential to the discipline of Management Accounting. The application and discussion of these dimensions in relation to Management Accounting Self-efficacy follows.

Self-Efficacy Dimension Theory of Management Accounting: The current section explores the impact of these three dimensions of Self-efficacy on Management Accounting. Management accounting Self-efficacy means assessing the ability to evaluate information correlations and then use historical patterns to forecast and direct business judgments. Management Accounting is concerned with historical data or information and utilising the information to make judgments of what must transpire in the future. Moreover, it is not about not only simply collecting information or data, but rather includes formulating conclusions; defining and managing risks; evaluating information and using it for business decisions; planning and budgeting (e.g. 
compiling written statements or reviewing financial information). The study will explore the dimensions of Management Accounting in the context of Self-efficacy in the section below.

Attainable: The Management Accounting Self-efficacy magnitude can point towards the level of capability expected to work under pressure, working to deadlines, working long hours and heavy responsibilities. Hence, mistakes in the Management Accounting sphere can be very costly to the organisation. Therefore, learners with a high magnitude of Self-efficacy in Management Accounting may tend to consider themselves as capable of performing more challenging management tasks compared to those with lower Self-efficacy judgments. Put another way, the magnitude of Self-efficacy in Management Accounting could be determined in terms of the levels of support needed to execute a task. Students with a higher degree of Self-efficacy in Management Accounting could consider themselves confident in functioning independently with less support and guidance than those who have less Self-efficacy judgments.

Generalisability: Self-efficacy generalizability reflects on the degree to which the judgment is limited to a particular domain of activity as indicated by Bandura. Within the Accounting context, these domains may well be considered to reflect analytical, advisory, decision-making and soft skills of trained management accountants. As a result, learners with high degree of Management Accounting Self-efficacy generalisability will be able to use a wide range of skills competently. The range of skills are namely in Identifying and Managing Risks; Analysing Information (using it to make business decisions); Planning and Budgeting. However, those with low Management Accounting Self-efficacy generalisability would perceive their capabilities as limited to particular aspects of Management Accounting.

Strength: The strength of Management Accounting Self-efficacy judgment relates to the level of trust about the decision, or the confidence that a learner has regarding their ability to perform the various tasks as discussed above. Thus, not only would learners by way of high Management Accounting Self-efficacy perceive themselves as able to accomplish more challenging tasks (high magnitude), but the learners would demonstrate better confidence about their ability to successfully perform each of the activities.

\section{Methodology}

Research Design: Since qualitative and quantitative methodology approaches complement each other, the current study made use of both methods.

Target Population: The target population considered for the current study were first year learners registered for Cost and Management Accounting at Mangosuthu University of Technology (MUT) and DUT and all DUT and MUT Management Accounting lecturers.

Sampling Techniques: A census survey was considered to be a more appropriate method and relevant to the present study and therefore implemented.

Sample Size: The sample size that was deemed appropriate for the study in progress are as follows:

- The control group:

The first year learners registered for Cost and Management Accounting at MUT.

- The experimental group:

The first year learners registered for Cost and Management Accounting at the DUT.

Data Collection Method: For the purposes of this study, the questionnaires (quantitative method) were issued to Cost and Management Accounting learners to ascertain the level of Self-efficacy. The administration of the questionnaires took place at two stages. The first stage was at the time of the learners enrolment and then a follow up took place towards the completion of the learners second year of study. The researcher carried out the dissemination and collection of the questionnaires of all the respondents.

Data Analysis: In the present research paper, the inferential statistics that was used included Cronbach Alpha, Correlation Analysis, Bar charts, Cross-tabulations, T-tests and ANOVA. The quantitative data was captured using the computer software package known as Statistical Package for Social Sciences (SPSS) under 
the guidance of a statistician. The quantitative data analysis was performed using Predictive Analytic Software (PASW) Statistics and Pearson Chi-Square Tests. The qualitative data was analysed according to recurring themes. Chapter 5 reports on the phase.

\section{Results \& Discussion}

Learners' Self-Efficacy Status: The level of Self-efficacy of learners was based on the pre-test and post-test in the following areas:

- Problem-Solving and Logical Reasoning;

- Learning and Performance;

- Perceived academic control;

- $\quad$ Self-Learning (Note-Taking);

- Self-Learning (Studying);

- $\quad$ Self-Learning (Test Preparation);

- Self-Learning (Reading);

- Self-Learning (Writing).

Problem-Solving and Logical Reasoning: Table 1 illustrates the respondents' problem-solving and logical reasoning ability. Pertaining to the learners' problem-solving and logical reasoning ability, the study found that the mean values were all above three, indicating that the levels are closer to agreement with the problem-solving and logical reasoning statements in the questionnaire. A similar status quo was found to be also true for the pre-test and post-test for both institutions, as well as the overall scores where the mean values were all above three. The gaps, which refer to the difference between the pre-test and post-test, were all positive, indicating that the post-test scores were higher than the pre-test scores. The gaps for DUT were higher than MUT.

Table 1: Problem Solving and Logical Reasoning

\begin{tabular}{|c|c|c|c|c|c|c|c|c|c|c|c|c|c|c|}
\hline \multirow{3}{*}{ (2) } & & \multicolumn{3}{|c|}{ DUT } & \multicolumn{3}{|c|}{ MUT } & \multicolumn{3}{|c|}{ Overall } & \multirow{3}{*}{$\begin{array}{l}\text { DUT } \\
\text { (Pre } \\
\text { vs } \\
\text { Post) } \\
\text { p- } \\
\text { value }\end{array}$} & \multirow{3}{*}{$\begin{array}{l}\text { MUT } \\
\text { (Pre } \\
\text { vs } \\
\text { Post) } \\
\text { p- } \\
\text { value }\end{array}$} & \multirow{2}{*}{$\begin{array}{l}\text { Overall } \\
\text { (Pre vs } \\
\text { Post) } \\
\text { p-value }\end{array}$} & $\begin{array}{l}\text { DUT vs } \\
\text { MUT }\end{array}$ \\
\hline & & $P$ & $\mathrm{P}$ & G & $P$ & $P$ & G & $P$ & $P$ & G & & & & Gap \\
\hline & & $\mathrm{r}$ & o & $\mathrm{a}$ & $\mathrm{r}$ & 0 & $\mathrm{a}$ & $r$ & o & a & & & & Score \\
\hline & & e & $\begin{array}{l}s \\
t\end{array}$ & $\mathrm{p}$ & e & $\begin{array}{l}s \\
t\end{array}$ & $\mathrm{p}$ & e & $\begin{array}{l}s \\
t\end{array}$ & $\mathrm{p}$ & & & & $\begin{array}{l}\text { Compar } \\
\text { ison }\end{array}$ \\
\hline \multirow{3}{*}{$\begin{array}{l}\text { I always manage to solve } \\
\text { difficult problems if I try } \\
\text { hard enough }\end{array}$} & 2 & 3 & 4 & 0 & 3 & 3 & 0 & 3 & 3 & 0 & 0.000 & 0.083 & 0.000 & 0.000 \\
\hline & 1 & 5 & 0 & 5 & 6 & 7 & 0 & 6 & 8 & 2 & & & & \\
\hline & & 3 & 5 & 2 & 6 & 1 & 5 & 0 & 8 & 8 & & & & \\
\hline \multirow{6}{*}{$\begin{array}{l}\text { When I am confronted } \\
\text { with a problem, I can } \\
\text { usually find several } \\
\text { solutions } \\
\text { If I am in trouble, I can } \\
\text { usually think of a solution }\end{array}$} & 2 & 3 & 3 & 0 & 3 & 3 & 0 & 3 & 3 & 0 & 0.000 & 1.000 & 0.000 & 0.000 \\
\hline & 2 & 2 & 7 & 4 & 3 & 3 & 0 & 3 & 5 & 2 & & & & \\
\hline & & 6 & 2 & 5 & 4 & 4 & 0 & 0 & 3 & 2 & & & & \\
\hline & 2 & 3 & 3 & 0 & 3 & 3 & 0 & 3 & 3 & 0 & 0.000 & 0.157 & 0.000 & 0.000 \\
\hline & 3 & i & 9 & 3 & 6 & 6 & 0 & 6 & 8 & 1 & & & & \\
\hline & & 1 & 7 & 6 & 3 & 6 & 3 & 2 & 1 & 9 & & & & \\
\hline
\end{tabular}

There were significant differences observed for DUT between pre and post-test for the problem solving and logical reasoning statements as all of the $\mathrm{p}$-values were $0.000(\mathrm{p}<0.001)$. The pre-test vs post-test scores for MUT were similar as all of the p-values are greater than 0.05 , implying that there are no significant differences. There was a significant difference in the overall scores owing to the DUT contribution. As indicated in the figure, the gap scores for DUT are significantly higher than MUT $(p<0.001)$. Although the pre-test scores for MUT are slightly higher than DUT, the post-test scores of DUT were higher than the MUT post-test scores. In all instances (pre-test, post-test and overall analysis) with both institutions, the learners' 
problem confrontation and finding solutions (statement 2.2) scored the lowest. Although there was an improvement in the post-test score with DUT respondents, it was still an issue.

Learning and Performance: Table 2 illustrate the respondents' of both DUT and MUT learning and performance.

Table 2: Learning and Performance

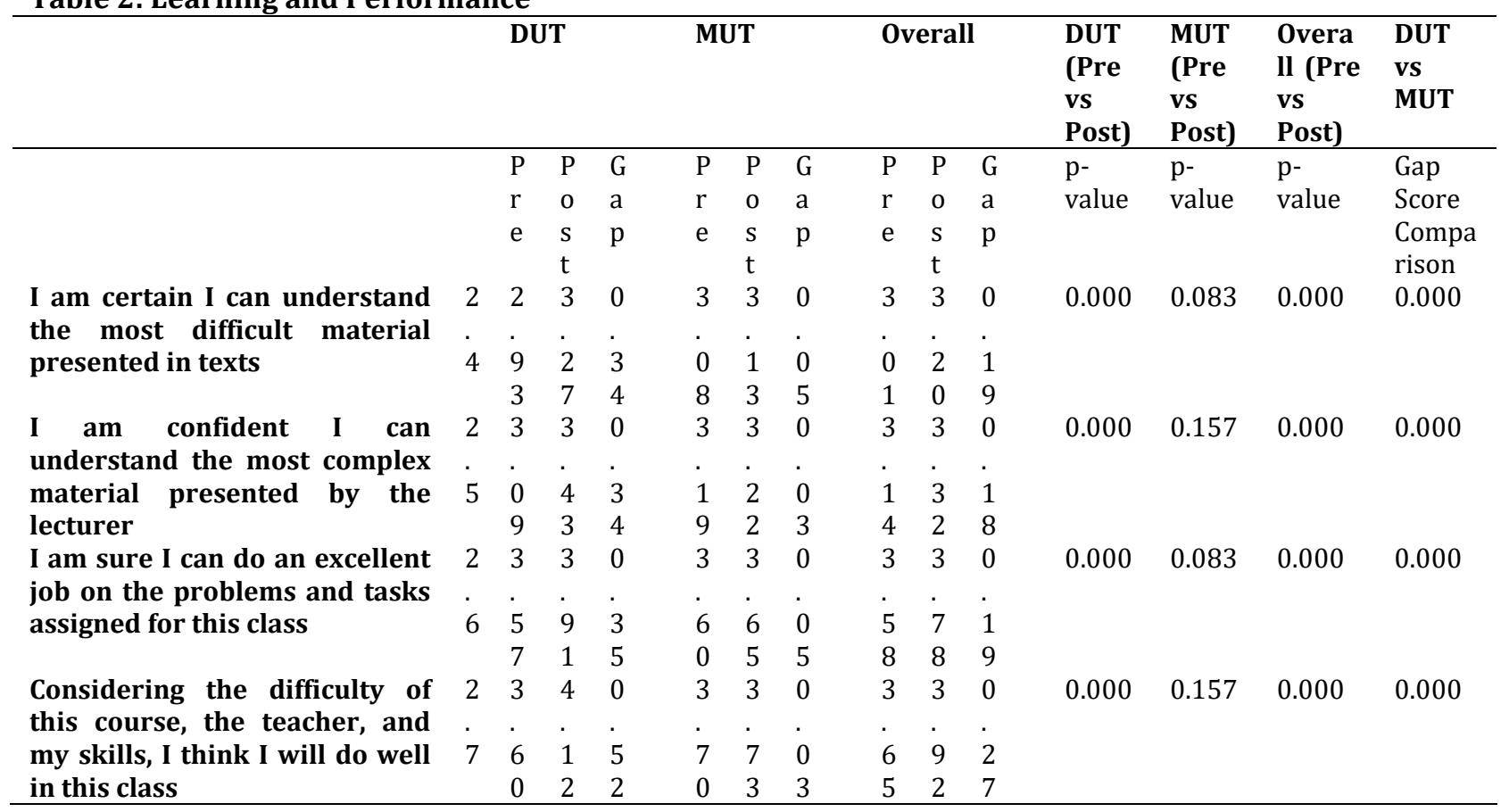

There was a significant difference between the pre-test and post-test scores for DUT regarding all of the statements on learning and performance $(p<0.05)$. The scoring patterns for MUT were similar between the pre-test and post-test for all statements $(\mathrm{p}>0.05)$. There were larger gap scores for DUT than there were for MUT. There were significant differences in all the gap scores for DUT. It is noted that all of the gap scores for DUT were positive, implying that the post-test scores were higher than the pre-test scores. The scoring patterns for 2.6 and 2.7 were higher than for the remaining statements. The average scores approximating 3 (the neutral score) indicated higher levels of neutral scoring (as verified by the frequency tables). In all instances with both institutions on the subject of understanding, the most difficult material presented in texts 2.4 scored the lowest.

Perceived Academic Control: Table 3 illustrates respondents' perceived academic control of both DUT and MUT institutions. There was a significant difference in the pre-test vs post-test scores $(\mathrm{p}<0.05)$ for both DUT and MUT, except statement Q2.10 for DUT and statement Q2.9 for MUT. The post-test scores are larger than the pre-test scores (as all of the gaps are positive). The gap scores are similar for statement Q2.10 ( $p=0.672)$. The statements for Q2.9, Q2.11 and Q2.12 have large post-test means for both institutions. The DUT post-test scores (and hence the gap scores) were higher than MUT. 
Table 3: Perceived Academic Control

\begin{tabular}{|c|c|c|c|c|c|c|c|c|c|c|c|c|c|c|}
\hline & & \multicolumn{3}{|c|}{ DUT } & \multicolumn{3}{|c|}{ MUT } & \multicolumn{3}{|c|}{ Overall } & $\begin{array}{l}\text { DUT } \\
\text { (Pre } \\
\text { vs } \\
\text { Post) } \\
\end{array}$ & $\begin{array}{l}\text { MUT } \\
\text { (Pre } \\
\text { vs } \\
\text { Post) }\end{array}$ & $\begin{array}{l}\text { Overal } \\
\text { l (Pre } \\
\text { vs } \\
\text { Post) }\end{array}$ & $\begin{array}{l}\text { DUT } \\
\text { vs } \\
\text { MUT }\end{array}$ \\
\hline & & $\mathrm{P}$ & $P$ & $\mathrm{Ga}$ & $\mathrm{P}$ & $P$ & $\mathrm{Ga}$ & $\mathrm{Pr}$ & $\mathrm{P}$ & $\mathrm{G}$ & p- & & & Gap \\
\hline & & $r$ & o & $\mathrm{p}$ & $r$ & 0 & $\mathrm{p}$ & $\mathrm{e}$ & o & a & value & value & value & Score \\
\hline & & $\mathrm{e}$ & s & & $\mathrm{e}$ & $\mathrm{s}$ & & & $\mathrm{s}$ & $\mathrm{p}$ & & & & Compa \\
\hline & & & $\mathrm{t}$ & & & $\mathrm{t}$ & & & $\mathrm{t}$ & & & & & rison \\
\hline \multirow{2}{*}{$\begin{array}{l}\text { Thanks to my } \\
\text { resourcefulness, I know }\end{array}$} & 2 & 3 & 3 & 0.5 & 3 & 3 & 0.0 & 3.0 & 3 & 0 & 0.000 & 0.025 & 0.000 & 0.000 \\
\hline & 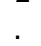 & . & . & 4 & . & . & 8 & 5 & . & . & & & & \\
\hline \multirow{2}{*}{$\begin{array}{l}\text { how to handle } \\
\text { unforeseen situations }\end{array}$} & 8 & 0 & 5 & & 0 & 1 & & & 3 & 3 & & & & \\
\hline & & 0 & 4 & & 9 & 7 & & & 5 & 0 & & & & \\
\hline \multirow{4}{*}{$\begin{array}{l}\text { I am interested in } \\
\text { classes/training }\end{array}$} & 2 & 3 & 4 & 0.4 & 3 & 3 & 0.0 & 3.9 & 4 & 0 & 0.000 & 1.000 & 0.000 & 0.000 \\
\hline & . & . & . & 0 & . & . & 0 & 9 & . & . & & & & \\
\hline & 9 & 9 & 3 & & 9 & 9 & & & 1 & 2 & & & & \\
\hline & & 9 & 9 & & 8 & 8 & & & 8 & 0 & & & & \\
\hline \multirow{4}{*}{$\begin{array}{l}\text { I } \quad \text { have } \\
\text { responsibilities }\end{array}$} & 2 & 3 & 3 & 0.1 & 3 & 3 & 0.0 & 3.1 & 3 & 0 & 0.315 & 0.025 & 0.095 & 0.672 \\
\hline & & . & . & 4 & . & . & 8 & 3 & . & . & & & & \\
\hline & 1 & 1 & 2 & & 1 & 2 & & & 2 & 1 & & & & \\
\hline & 0 & 2 & 6 & & 4 & 2 & & & 4 & 1 & & & & \\
\hline \multirow{4}{*}{$\begin{array}{l}\text { I have the necessary } \\
\text { motivation }\end{array}$} & 2 & 3 & 3 & 0.3 & 3 & 3 & 0.1 & 3.5 & 3 & 0 & 0.000 & 0.014 & 0.000 & 0.001 \\
\hline & $\cdot$ & . & . & 8 & . & . & 0 & 8 & . & . & & & & \\
\hline & 1 & 6 & 9 & & 5 & 6 & & & 8 & 2 & & & & \\
\hline & 1 & 1 & 9 & & 5 & 5 & & & 1 & 4 & & & & \\
\hline \multirow[t]{4}{*}{ I am talented enough } & 2 & 3 & 3 & 0.6 & 3 & 3 & 0.0 & 3.2 & 3 & 0 & 0.000 & 0.046 & 0.000 & 0.000 \\
\hline & . & . & . & 3 & . & . & 7 & 2 & . & . & & & & \\
\hline & 1 & 1 & 7 & & 3 & 4 & & & 5 & 3 & & & & \\
\hline & 2 & 1 & 4 & & 3 & 0 & & & 7 & 4 & & & & \\
\hline
\end{tabular}

Self-Learning (Note-Taking): Table 4 illustrates the respondents' self-learning (note-taking) abilities at both DUT and MUT. Regarding the section on self-learning in note-taking, there was a significant difference in all of the $\mathrm{p}$-values $(\mathrm{p}<0.05)$, with the exception being for the pre-test vs post-test comparison for statement Q2.16. The mean pre-test and post-test scores for DUT are all above 3, with similar patterns observed for MUT, except for statement Q2.14, which are less than 3. An inspection of the frequency tables indicates that for statement Q2.14, there was a 32.1\% disagreement for the pre-test and 28.3\% disagreement for post-test for MUT. The levels of disagreement were higher for MUT as compared to DUT. In all instances (pre-test, posttest and overall analysis) with both institutions, about writing an effective summary of the original notes before the next class (statement 2.14) scored the lowest. For a learner to write an effective summary of the original notes requires the ability of note-taking. Note-taking is not just about taking or scribbling notes down. Note-taking is an essential tool for understanding, learning and ultimately having a positive influence on learner performance.

Table 4: Self-Learning (Note-Taking)

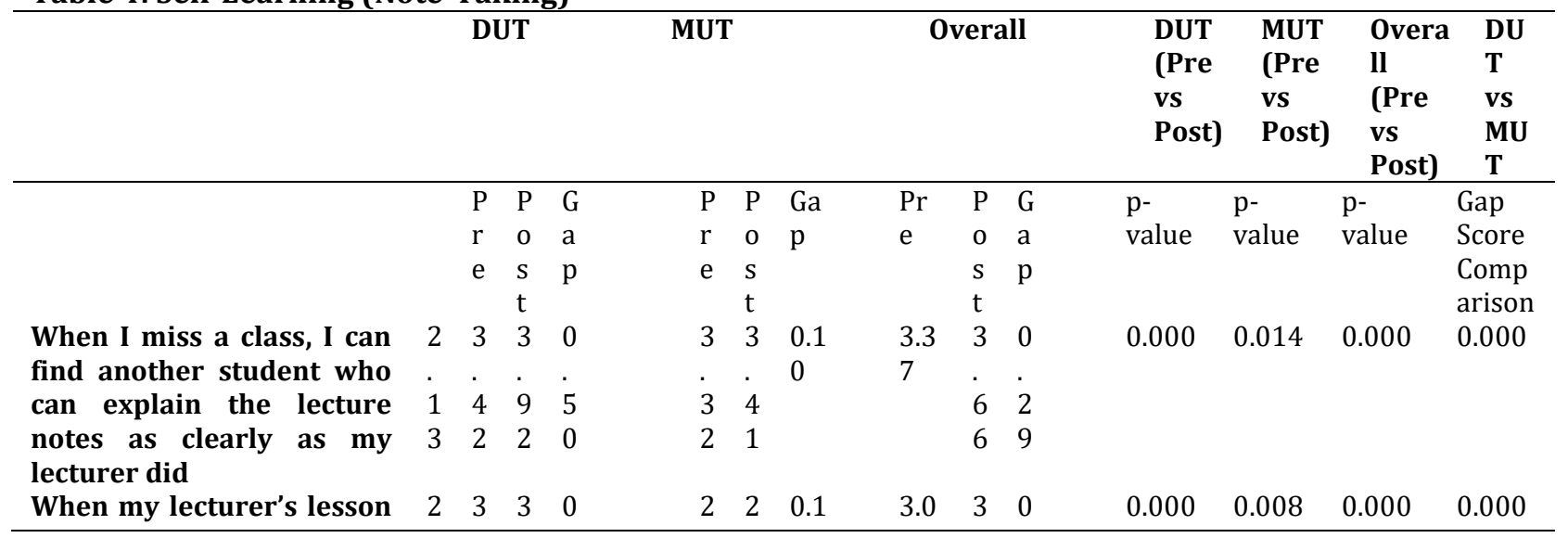




\begin{tabular}{|c|c|c|c|c|c|c|c|c|c|c|c|c|c|c|}
\hline is very complex, I can & . & . & . & . & . & . & 1 & 3 & . & . & & & & \\
\hline effective & 1 & 1 & 5 & 3 & 8 & 9 & & & 2 & 2 & & & & \\
\hline $\begin{array}{l}\text { summary of the original } \\
\text { notes before the next class }\end{array}$ & 4 & 8 & 7 & 9 & 8 & 9 & & & 8 & 5 & & & & \\
\hline When I have trouble & 2 & 3 & 3 & 0 & 3 & 3 & 0.0 & 3.3 & 3 & 0 & 0.000 & 0.025 & 0.000 & 0.000 \\
\hline studying the class notes & . & . & . & . & . & . & 8 & 8 & . & . & & & & \\
\hline because they are & 1 & 4 & 8 & 4 & 3 & 3 & & & 6 & 2 & & & & \\
\hline $\begin{array}{l}\text { incomplete or confusing, I } \\
\text { can revise and rewrite } \\
\text { them clearly after every } \\
\text { lecture }\end{array}$ & 5 & 5 & 6 & 1 & 1 & 9 & & & 2 & 4 & & & & \\
\hline When I am taking a course & 2 & 3 & 3 & 0 & 3 & 3 & 0.0 & 3.3 & 3 & 0 & 0.000 & 0.083 & 0.000 & 0.000 \\
\hline covering a huge amount of & $\cdot$ & . & 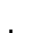 & $\cdot$ & . & 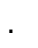 & 5 & 5 & . & . & & & & \\
\hline material, I can condense & 1 & 3 & 8 & 5 & 3 & 4 & & & 6 & 2 & & & & \\
\hline $\begin{array}{l}\text { my notes down to just the } \\
\text { essential facts }\end{array}$ & 6 & 4 & 4 & 0 & 5 & 0 & & & 1 & 7 & & & & \\
\hline
\end{tabular}

Self-Learning (Studying): Table 5 illustrate the respondents' self-learning (studying) abilities at both DUT and MUT. On the subject of the learners' self-learning in respect of studying ability, the study found that the mean values were all above three, indicating that the levels are closer to agreement with the self-learning (studying) statements in the questionnaire. There was a significant difference in most of the values, except for statement Q2.18 and statement Q2.20 for MUT. The DUT post-test scores (and hence the gap scores) were higher and positive as compared to MUT. In all cases with both institutions on the subject of recognizing a new topic and associating new concepts with old ones, the lowest score was reasonably well to recall them (statement 2.17).

Table 5: Self-Learning (Studying)

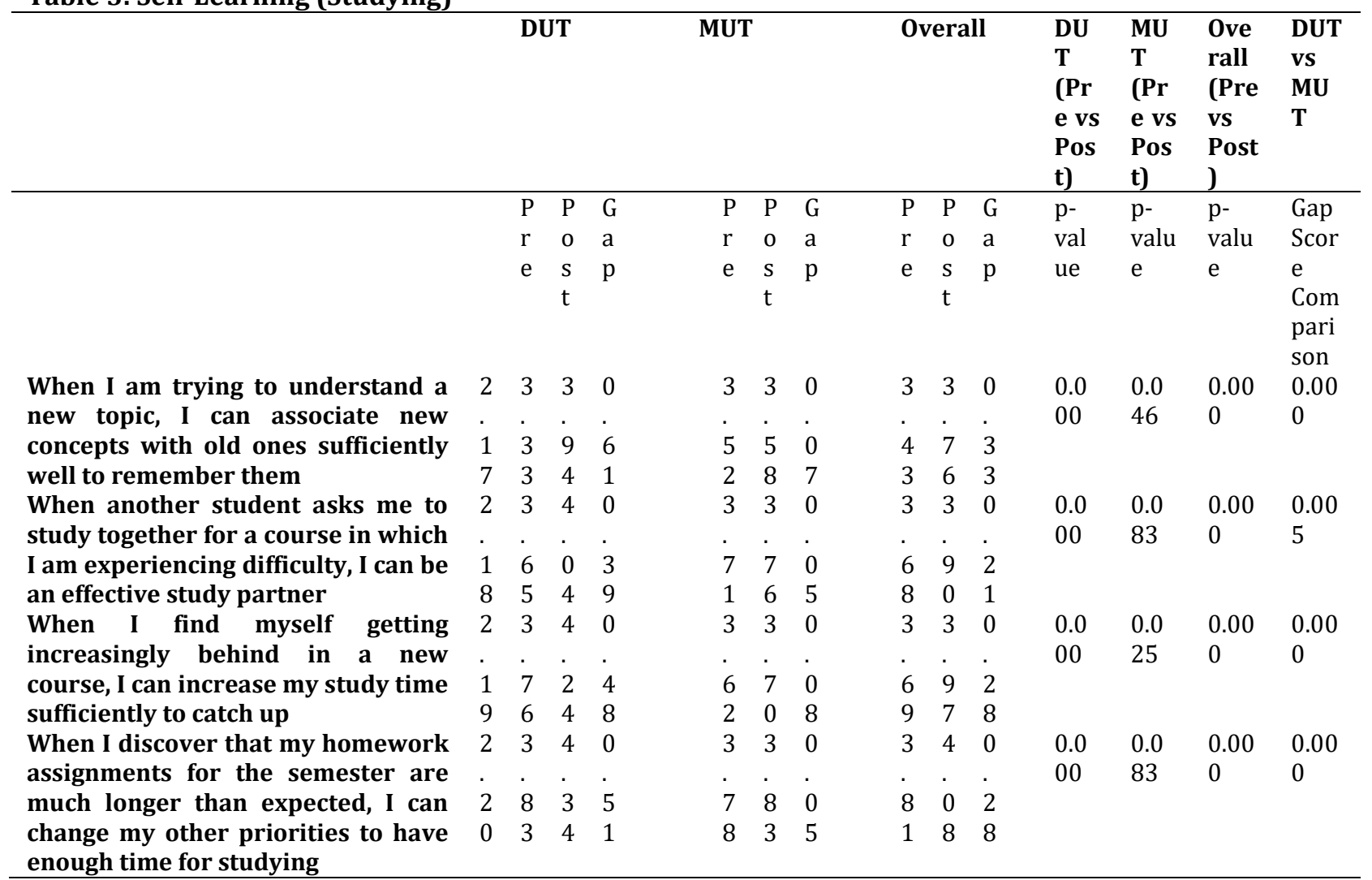

Self-Learning (Test Preparation): Table 6 illustrate the respondents' self-learning (test preparation) abilities of both DUT and MUT institutions. 


\begin{tabular}{llllll} 
& & & & & \\
\hline & P & P & G & Pre \\
& r & o & a & \\
e & s & p & \\
& & t & &
\end{tabular}

\begin{tabular}{|c|c|c|c|c|c|c|c|c|c|c|c|c|c|c|}
\hline $\begin{array}{l}\text { When I am feeling depressed about a } \\
\text { forthcoming test, I can find a way to } \\
\text { motivate myself to do well }\end{array}$ & $\begin{array}{l}2 \\
2 \\
2 \\
1\end{array}$ & $\begin{array}{l}3 \\
. \\
6 \\
5\end{array}$ & $\begin{array}{l}4 \\
2 \\
0\end{array}$ & $\begin{array}{l}5 \\
5\end{array}$ & 3.56 & $\begin{array}{l}3 \\
6 \\
6 \\
1\end{array}$ & $\begin{array}{l}0.0 \\
5\end{array}$ & $\begin{array}{l}3 \\
5 \\
6 \\
0\end{array}$ & $\begin{array}{l}3 \\
9 \\
9\end{array}$ & $\begin{array}{l}0 \\
5 \\
2 \\
9\end{array}$ & $\begin{array}{l}0.00 \\
0\end{array}$ & $\begin{array}{l}0.08 \\
3\end{array}$ & 0.000 & 0.000 \\
\hline $\begin{array}{l}\text { When I am struggling to remember } \\
\text { technical details of a concept for a } \\
\text { test, I can find a way to associate them } \\
\text { together that will ensure recall }\end{array}$ & $\begin{array}{l}2 \\
. \\
2 \\
2\end{array}$ & $\begin{array}{l}4 \\
8\end{array}$ & $\begin{array}{l}3 \\
. \\
8 \\
9\end{array}$ & $\begin{array}{l}4 \\
1\end{array}$ & 3.32 & $\begin{array}{l}3 \\
. \\
4 \\
0\end{array}$ & $\begin{array}{l}0.0 \\
8\end{array}$ & $\begin{array}{l}3 \\
. \\
4 \\
0\end{array}$ & $\begin{array}{l}3 \\
6 \\
6\end{array}$ & $\begin{array}{l}0 \\
5 \\
2 \\
4\end{array}$ & $\begin{array}{l}0.00 \\
0\end{array}$ & $\begin{array}{l}0.02 \\
5\end{array}$ & 0.000 & 0.000 \\
\hline $\begin{array}{l}\text { When I have to take a test in a subject } \\
\text { I dislike, I can find a way to motivate } \\
\text { myself to earn a good grade }\end{array}$ & $\begin{array}{l}2 \\
. \\
2 \\
3\end{array}$ & $\begin{array}{l}4 \\
8\end{array}$ & $\begin{array}{l}4 \\
. \\
0 \\
2\end{array}$ & $\begin{array}{l}5 \\
3\end{array}$ & 3.44 & $\begin{array}{l}5 \\
0\end{array}$ & $\begin{array}{l}0.0 \\
7\end{array}$ & $\begin{array}{l}3 \\
4 \\
6\end{array}$ & $\begin{array}{l}3 \\
7 \\
7 \\
5\end{array}$ & $\begin{array}{l}3 \\
0\end{array}$ & $\begin{array}{l}0.00 \\
0\end{array}$ & $\begin{array}{l}0.04 \\
6\end{array}$ & 0.000 & 0.000 \\
\hline $\begin{array}{l}\text { When I think I did poorly on a test } \\
\text { that I just finished, I can go back to my } \\
\text { notes and locate all the information I } \\
\text { had forgotten }\end{array}$ & $\begin{array}{l}2 \\
. \\
2 \\
4\end{array}$ & $\begin{array}{l}7 \\
6 \\
\end{array}$ & $\begin{array}{l}3 \\
. \\
8 \\
9\end{array}$ & $\begin{array}{l}1 \\
2 \\
\end{array}$ & 3.40 & $\begin{array}{l}5 \\
2 \\
\end{array}$ & $\begin{array}{l}0.1 \\
2\end{array}$ & $\begin{array}{l}5 \\
8\end{array}$ & $\begin{array}{l}3 \\
7 \\
7 \\
0\end{array}$ & $\begin{array}{l}1 \\
2 \\
\end{array}$ & $\begin{array}{l}0.10 \\
0\end{array}$ & $\begin{array}{l}0.00 \\
8\end{array}$ & 0.013 & 0.085 \\
\hline
\end{tabular}

On the subject of the learners' self-learning with regard to test preparation ability, the study found that the mean values were all above three, indicating that the levels are closer to agreement with the self-learning (test preparation) statements in the questionnaire. There was a significant difference in most of the values, except for statement 2.24 for DUT and statement 2.21 regarding MUT. The post-test scores for DUT were higher than MUT post-test scores.

Self-Learning (Reading): Table 7 illustrates the respondents' self-learning (reading) abilities at both DUT and MUT. On the topic of self-learning and reading ability, the study found that the mean values were all above three, suggesting that the rates are closer to agreement on the questionnaire's self-learning (reading) claims. There was a significant difference in all the values, except for statement Q2.26 for the pre-test vs posttest for MUT. The scores for DUT were higher than MUT. The gaps, which refer to the difference between the pre-test and post-test, were all positive, indicating that the post-test scores were higher than the pre-test scores. The gaps for DUT were higher than MUT.

Table 7: Self-Learning (Reading)

\begin{tabular}{|c|c|c|c|c|c|c|c|c|c|c|c|c|c|c|}
\hline & & \multicolumn{3}{|c|}{ DUT } & \multicolumn{3}{|c|}{ MUT } & \multicolumn{3}{|c|}{ Overall } & \multirow{3}{*}{$\begin{array}{l}\text { DUT } \\
\text { (Pre } \\
\text { vs } \\
\text { Post } \\
\text { J } \\
\text { p- } \\
\text { value }\end{array}$} & \multirow{3}{*}{$\begin{array}{l}\text { MUT } \\
\text { (Pre } \\
\text { vs } \\
\text { Post) } \\
\text { p- } \\
\text { value }\end{array}$} & \multirow{3}{*}{$\begin{array}{l}\text { Overa } \\
\text { ll } \\
\text { (Pre } \\
\text { vs } \\
\text { Post) } \\
\text { p- } \\
\text { value }\end{array}$} & $\begin{array}{l}\text { DUT } \\
\text { vs } \\
\text { MUT }\end{array}$ \\
\hline & & $\mathrm{P}$ & $P$ & $\mathrm{G}$ & Pre & $\mathrm{P}$ & Ga & $P$ & $\mathrm{P}$ & $G$ & & & & Gap \\
\hline & & $r$ & o & $\mathrm{a}$ & & o & $\mathrm{p}$ & $\mathrm{r}$ & 0 & $\mathrm{a}$ & & & & Score \\
\hline & & $\mathrm{e}$ & $\mathrm{s}$ & $\mathrm{p}$ & & $\mathrm{s}$ & & e & $\mathrm{s}$ & $\mathrm{p}$ & & & & Comp \\
\hline & & & $\mathrm{t}$ & & & $\mathrm{t}$ & & & $\mathrm{t}$ & & & & & arison \\
\hline & 2 & 3 & 3 & 0 & 3.4 & 3 & 0.0 & 3 & 3 & 0 & 0.00 & 0.046 & 0.000 & 0.000 \\
\hline \multirow{7}{*}{$\begin{array}{l}\text { When I notice I am having trouble } \\
\text { concentrating on a reading } \\
\text { assignment, I can refocus my } \\
\text { attention and learn the material } \\
\text { When I don't understand a } \\
\text { paragraph I have just read, I can } \\
\text { clarify it by careful re-reading }\end{array}$} & . & . & . & . & 8 & 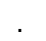 & 7 & - & & . & 0 & & & \\
\hline & 2 & 4 & 9 & 5 & & 5 & & 4 & 7 & 3 & & & & \\
\hline & 5 & 3 & 5 & 3 & & 5 & & 5 & 5 & 0 & & & & \\
\hline & 2 & 3 & 4 & 0 & 3.8 & 3 & 0.0 & 3 & 4 & 0 & 0.00 & 0.317 & 0.000 & 0.000 \\
\hline & . & . & . & . & 8 & . & 2 & . & . & . & 0 & & & \\
\hline & 2 & 7 & 2 & 5 & & 8 & & 8 & 0 & 2 & & & & \\
\hline & 6 & 3 & 5 & 2 & & 9 & & 0 & 7 & 7 & & & & \\
\hline \multirow{4}{*}{$\begin{array}{l}\text { When I have trouble recalling key } \\
\text { facts in a reading assignment, I can } \\
\text { find a way to remember all of these } \\
\text { two weeks later }\end{array}$} & 2 & 3 & 3 & 0 & 3.0 & 3 & 0.0 & 3 & 3 & 0 & 0.00 & 0.025 & 0.000 & 0.014 \\
\hline & r. & . & . & . & 1 &. & 8 & & & & 2 & & & \\
\hline & 2 & 2 & 5 & 3 & & 1 & & 1 & 3 & 2 & & & & \\
\hline & 7 & 5 & 5 & 1 & & 0 & & 3 & 2 & 0 & & & & \\
\hline
\end{tabular}


Self-Learning (Writing): Table 8 illustrates the respondents' self-learning (writing) abilities.

Table 8: Self-Learning (Writing)

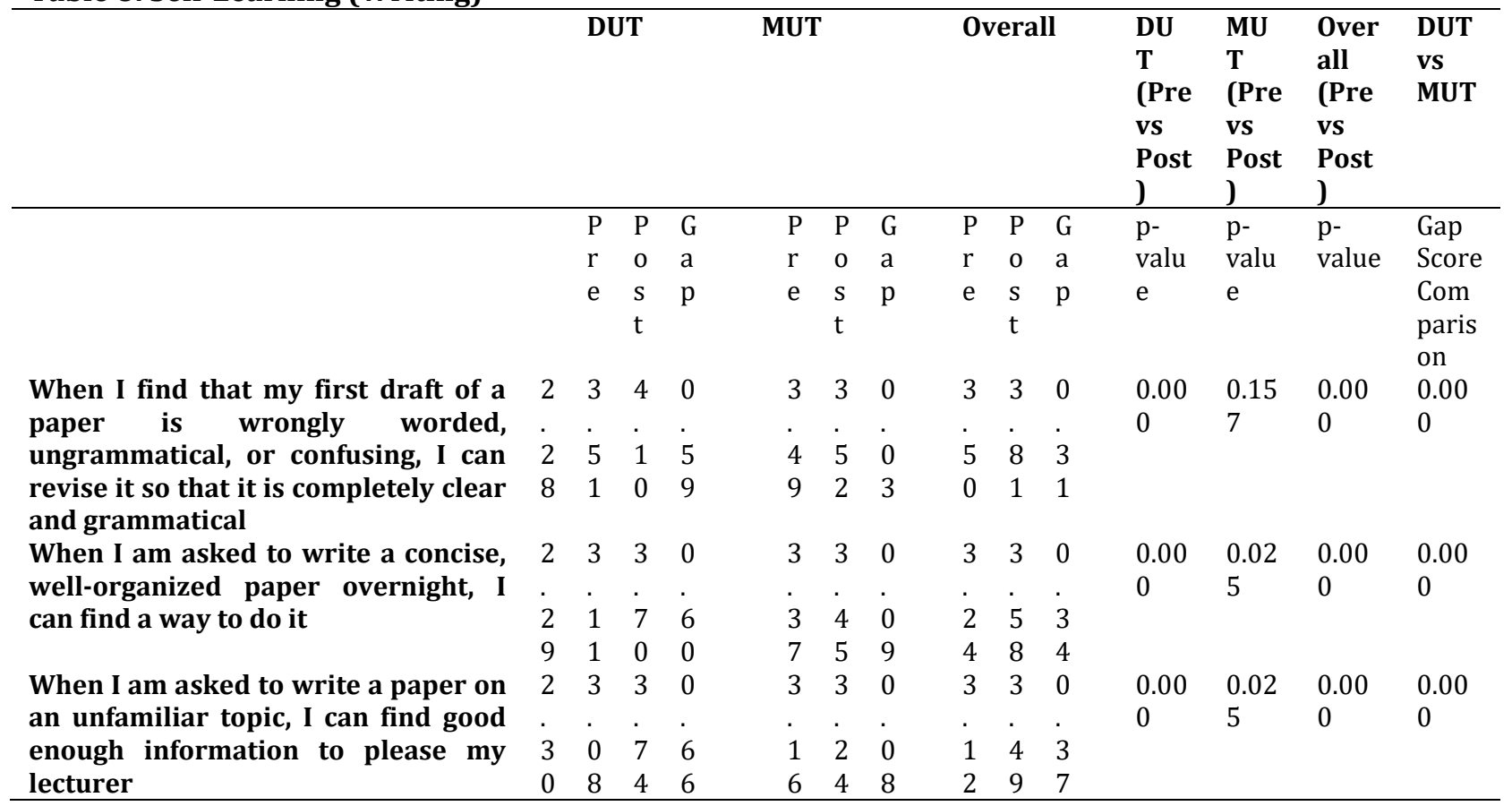

On the topic of the learners' self-learning with regard to writing ability, the study found that the mean values were all above three, indicating that the levels are closer to agreement with the self-learning (writing) statements in the questionnaire. There was a significant difference in all values except for statement Q2.28 for pre-test vs post-test for MUT. The post-test scores for DUT were higher than that for MUT. The gaps observed for DUT were larger than MUT. The overall results between the pre-test (Self-efficacy) scores and post-test (Self-efficacy) scores of the group that undertook the General Education module revealed a significant percentage difference $(+9.1 \%)$ as indicated in Figure 3.

\section{Conclusion and Recommendations}

The findings indicate a significant correlation in the post-test (Self-efficacy) scores of the group that undertook the General Education Modules and not the group that did not undertake the General Education Modules.

Recommendations: The following model is recommended for assessing the impact of Self-efficacy on accounting learners' ability from year 1 to year 3 .

Model Measuring Self-Efficacy: Self-Efficacy refers to the belief in one's ability to complete specific tasks. Notes:

- Please answer questions as you actually are and not where you think you should be.

- Provide one response to each item.

- There are no right or wrong answers.

- Indicate the extent to which you agree or disagree with each of the following statements by placing a $\operatorname{cross}(X)$ in the appropriate box. 


\begin{tabular}{|c|c|c|c|c|c|}
\hline \multirow{2}{*}{ Disagree (D) } & \multirow{2}{*}{ A) } & \multicolumn{4}{|c|}{ Strongly Agree (SA) } \\
\hline & & D & $\mathbf{N}$ & A & SA \\
\hline \multicolumn{6}{|l|}{ Problem Solving and Logical Reasoning } \\
\hline I always manage to solve difficult problems if I try hard enough. & 1 & 2 & 3 & 4 & 5 \\
\hline When I am confronted with a problem, I can usually find several solutions. & 1 & 2 & 3 & 4 & 5 \\
\hline $\begin{array}{l}\text { If I am in trouble, I can usually think of a solution. } \\
\text { Learning and Performance }\end{array}$ & 1 & 2 & 3 & 4 & 5 \\
\hline $\begin{array}{l}\text { I am certain I can understand the most difficult material presented in } \\
\text { texts. }\end{array}$ & 1 & 2 & 3 & 4 & 5 \\
\hline $\begin{array}{l}\text { I am confident I can understand the most complex material presented by } \\
\text { the lecturer. }\end{array}$ & 1 & 2 & 3 & 4 & 5 \\
\hline $\begin{array}{l}\text { I am sure I can do an excellent job on the problems and tasks assigned for } \\
\text { this class. }\end{array}$ & 1 & 2 & 3 & 4 & 5 \\
\hline $\begin{array}{l}\text { Considering the difficulty of this course, the teacher, and my skills, I think I } \\
\text { will do well in this class. }\end{array}$ & 1 & 2 & 3 & 4 & 5 \\
\hline \multicolumn{6}{|l|}{ Perceived academic control } \\
\hline $\begin{array}{l}\text { Thanks to my resourcefulness, I know how to handle unforeseen } \\
\text { situations. }\end{array}$ & 1 & 2 & 3 & 4 & 5 \\
\hline I am interested in classes/training. & 1 & 2 & 3 & 4 & 5 \\
\hline I have family responsibilities. & 1 & 2 & 3 & 4 & 5 \\
\hline I have the necessary motivation. & 1 & 2 & 3 & 4 & 5 \\
\hline I am talented enough. & 1 & 2 & 3 & 4 & 5 \\
\hline \multicolumn{6}{|l|}{ Self-Learning (Note-Taking) } \\
\hline $\begin{array}{l}\text { When I miss a class, I can find another Learner who can explain the lecture } \\
\text { notes as clearly as my lecturer did. }\end{array}$ & 1 & 2 & 3 & 4 & 5 \\
\hline $\begin{array}{l}\text { When my lecturer's lesson is very complex, I can write an effective } \\
\text { summary of the original notes before the next class. }\end{array}$ & 1 & 2 & 3 & 4 & 5 \\
\hline $\begin{array}{l}\text { When I have trouble studying the class notes because they are incomplete } \\
\text { or confusing, I can revise and rewrite them clearly after every lecture. }\end{array}$ & 1 & 2 & 3 & 4 & 5 \\
\hline $\begin{array}{l}\text { When I am taking a course covering a huge amount of material, I can } \\
\text { condense my notes down to just the essential facts. } \\
\text { Self-Learning (Studying) }\end{array}$ & 1 & 2 & 3 & 4 & 5 \\
\hline $\begin{array}{l}\text { When I am trying to understand a new topic, I can associate new concepts } \\
\text { with old ones sufficiently well to remember them. }\end{array}$ & 1 & 2 & 3 & 4 & 5 \\
\hline \multirow{2}{*}{$\begin{array}{l}\text { When another Learner asks me to study together for a course in which I } \\
\text { am having trouble, I can be an effective study partner. }\end{array}$} & 1 & 2 & 3 & 4 & 5 \\
\hline & SD & D & $\mathbf{N}$ & $\mathbf{A}$ & SA \\
\hline $\begin{array}{l}\text { When I find myself getting increasingly behind in a new course, I can } \\
\text { increase my study time sufficiently to catch up. }\end{array}$ & 1 & 2 & 3 & 4 & 5 \\
\hline $\begin{array}{l}\text { When I discover that my homework assignments for the semester are } \\
\text { much longer than expected, I can change my other priorities to have } \\
\text { enough time for studying. } \\
\text { Self-Learning (Test Preparation) }\end{array}$ & 1 & 2 & 3 & 4 & 5 \\
\hline $\begin{array}{l}\text { When I am feeling depressed about a forthcoming test, I can find a way to } \\
\text { motivate myself to do well. }\end{array}$ & 1 & 2 & 3 & 4 & 5 \\
\hline \multicolumn{6}{|l|}{$\begin{array}{l}\text { When I have to take a test in a subject I dislike, I can find a way to motivate } \\
\text { myself to earn a good grade. }\end{array}$} \\
\hline $\begin{array}{l}\text { When I am struggling to remember technical details of a concept for a test, } \\
\text { I can find a way to associate them together that will ensure recall. }\end{array}$ & 1 & 2 & 3 & 4 & 5 \\
\hline $\begin{array}{l}\text { When I think I did poorly on a test that I just finished, I can go back to my } \\
\text { notes and locate all the information I had forgotten. } \\
\text { Self-Learning (Reading) }\end{array}$ & 1 & 2 & 3 & 4 & 5 \\
\hline $\begin{array}{l}\text { When I notice I am having trouble concentrating on a reading assignment, } \\
\text { I can refocus my attention and learn the material. }\end{array}$ & 1 & 2 & 3 & 4 & 5 \\
\hline When I do not understand a paragraph I have just read, I can clarify it by & 1 & 2 & 3 & 4 & 5 \\
\hline
\end{tabular}


careful rereading.

When I have trouble recalling key facts in a reading assignment, I can find $\begin{array}{llllllll}1 & 2 & 3 & 4 & 5\end{array}$

a way to remember all of these two weeks later.

Self-Learning (Writing)

When I find that my first draft of a paper is wrongly worded, $1 \begin{array}{llllll}2 & 3 & 4 & 5\end{array}$

ungrammatical, or confusing, I can revise it so that it is completely clear

and grammatical.

When I am asked to write a concise, well-organized paper overnight, I can $\begin{array}{llllllll}1 & 2 & 3 & 4 & 5\end{array}$

find a way to do it.

When I am asked to write a paper on an unfamiliar topic, I can find good $\begin{array}{lllllll}1 & 2 & 3 & 4 & 5\end{array}$ enough information to please my lecturer.

Gap Analysis between Pre-Test and Post-Test Using the Proposed Model: Figure 3 illustrates the overall gap analysis between pre-test and post-test, using the current study's proposed framework to measure the impact of Self-efficacy on Accounting learners' ability to communicate effectively from year 1 to year 3.

Figure 3: Overall Gap Analysis between Pre-Test and Post-Test

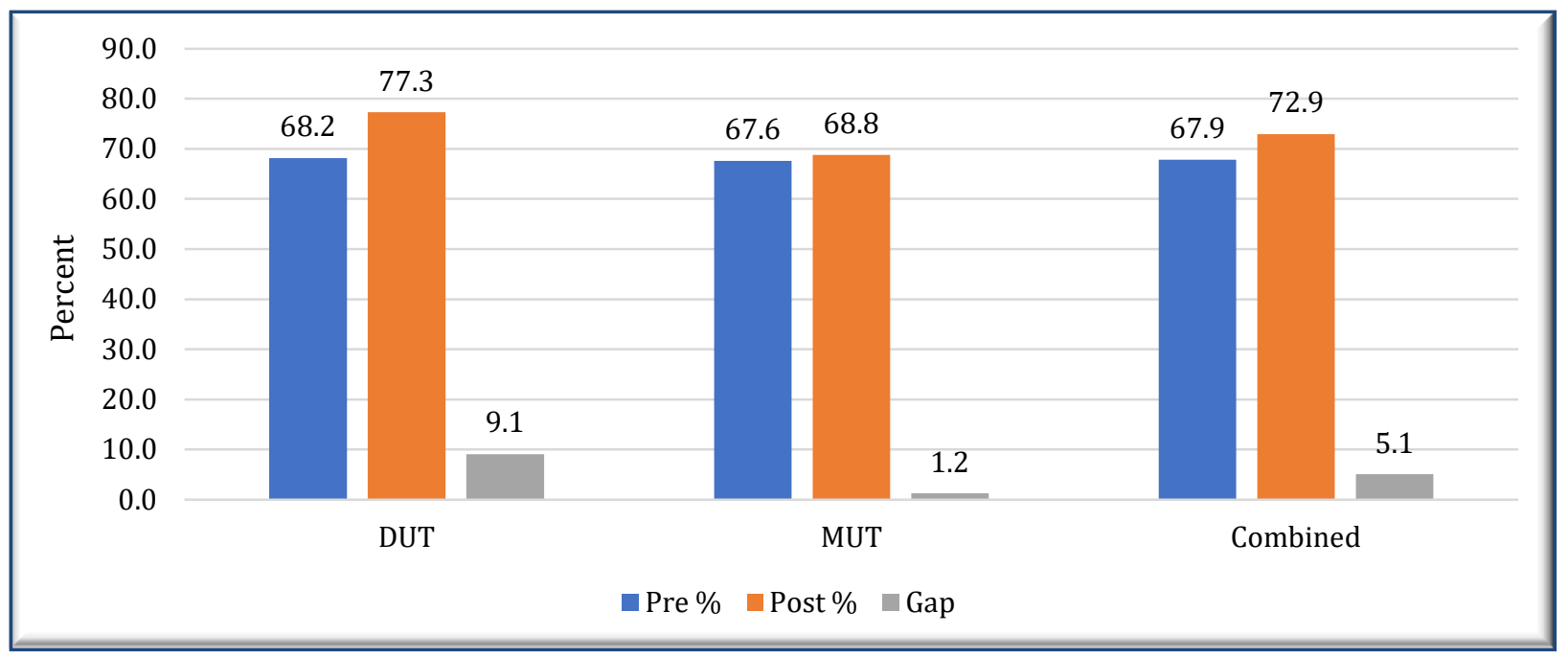

Figure 3 is a summary of the scoring patterns for the eight sections on the learners' Self-efficacy as indicated in the proposed framework of the current study (out of a maximum of 150) for the two institutions, as well as a combined score. It was noted that the pre-test scores are marginally higher for DUT, but that the post-test scores are much greater for DUT than MUT. The Wilcoxon Test was utilised to compare the pre-test score to post-test score for each institution. In both instances, there was a significant difference in the $p$-value ( $\mathrm{p}$ 0.001). The combined scores also showed the same trends with a significant difference in the $p$-value ( $<<$ 0.001). However, on comparison between both the institutions, DUT exhibited the largest positive Gap, indicating a much better post-test score than the pre-test score. The same trends were observed in the overall analysis.

Score Interpretation

\begin{tabular}{ll}
\hline Score & Comments \\
\hline $\mathbf{0 - 7 4}$ & You need to keep working on your communication and self-learning skills. You are not \\
& $\begin{array}{l}\text { expressing yourself clearly, and you may not be receiving messages or learning correctly. The } \\
\text { good news is that, by paying attention to communication and self-learning skills, you can be }\end{array}$ \\
& much more effective at your studies, and enjoy much better performance. \\
75-112 & $\begin{array}{l}\text { You are a competent communicator with good self-learning skills, but you at times experience } \\
\text { communication and self-learning issues. Take a moment to think about your approach to } \\
\text { communication and self-learning, and focus on receiving messages and learning effectively. } \\
\text { This will help you improve on your performance. }\end{array}$ \\
\hline
\end{tabular}



send messages, and when you receive them. You expect problems, and you choose the right ways of communicating and problem solving. People acknowledge you for your ability to communicate clearly and self-learn, and they appreciate your listening and self-learning skills.

Acknowledgements: "Matha Pitha Guru Deivam" is a very popular phrase in Sanskrit language and often mentioned in Hinduism. When translated word for word, it means "Mother, Father, Teacher and God". The meaning of this phrase is the greatest truth, and is the order in which one should offer reverence. The phrase is a basic ideology in existence from the time of the Vedas and beyond and signifies the hierarchy in which one should respect these entities. I would first like to thank my mother, Velliamah Naidoo, for first holding my hand and teaching me how to write. Without her continuous support and encouragement, I never would have been able to achieve my goals. This one is for you mom! Second, a very special thank you to my late father, Kristnasamy Naidoo. You have given me the greatest gift of all, education and the freedom of choice. I would not be who I am today without your support and I hope I have made you proud. "Sri Krishna said to Arjuna: But those who always worship me with exclusive devotion, meditating on my transcendental form - to them I carry what they lack, and I preserve what they have" (Bhagwat Gita: Chapter 9 verse 22). Thank you God for giving me the strength to complete my studies even when circumstances seemed impossible.

\section{References}

Baker, W. M. \& McGregor, C. C. (2000). Empirically assessing the importance of characteristics of accounting learners. Education for Business, 75(3), 149-157.

Bandura, A. (1977). Self-efficacy: toward a unifying theory of behavioural change. Psychological Review, 84(2), 191-215.

Bandura, A. (1994). Self-Efficacy. In: Ramachaudran. V. S. eds. Encyclopaedia of human. New York: Academic Press, 71-81.

Barac, K. (2009). South African training officers' perceptions of the knowledge and skills requirements of entry-level trainee accountants. Meditari Accountancy Research, 17(2), 19-46.

Best, J. W. \& Kahn, J. V. (2006). Research in Education. 10 $10^{\text {th }}$ ed. Boston, Massachusetts: Allyn and Bacon/Pearson Education.

Brief, A. P. \& Aldag, R. J. (1981). The 'self' in work organization: a conceptual review. Academy of Management Review, 6(1), 75-88.

Carlsen, W. (1999). Domains of teacher knowledge. In: Gess-Newsome, J and Lederman, N. G. eds. Examining pedagogical content knowledge. Netherlands: Kluwer Academic Publishers, 133-144.

Carver Learning Systems. (2019). Definition of rauding. Available: http://www.carverlearning.com/our-story (Accessed 12 October 2019).

Carver, R. P. (1978). Another look at rauding theory. Reading Research, 13(1), 116-132.

Centre for Development and Enterprise. (2011). Value in the classroom: the quantity and quality of South Africa's teachers. Johannesburg: Centre for Development and Enterprise.

Cherry, K. (2018). What is Self-Efficacy? Available: https://www.verywell.com/what-is-Self-efficacy-2795954 (Accessed 26 September 2018).

CIMA. (2010). National award for Management Accounting. Available: http://www.cimaglobal.com/Documents/Member percent20docs/nafma-APPENDIX.pdf (Accessed 14 September 2016).

Davis, M. (2012). Critical analysis of social cognition and social learning theory. Available: https://www.academia.edu/1469375/Critical_Analysis_of_Social_Cognition_and_Social_Learning_Th eory (Accessed 04 September 2018).

De Villiers, R. (2010). The incorporation of soft skills into accounting curricula: preparing accounting graduates for their unpredictable futures. Meditari Accountancy Research, 18(2), 1-22.

Deloitte Global Services. (2019). Formation and membership of IFAC. Available: http://www.iasplus.com/en/resources/global-organisations/ifac (Accessed 26 September 2019).

Department of Basic Education. (2014). National senior certificate examination 2014: diagnostic report. Pretoria: Department of Basic Education.

Facione, P. A. (2015). Critical thinking: what it is and why it counts. Hermosa Beach, California: Measured Reasons LLC. 
FASSET. (2011). Scarce skills guideline. Blackhealth, Randburg: FASSET.

Fawcett, A. (2015). Practical application of the international education standards (unpublished policy document).

Gist, M. E. \& Mitchell, T. R. (1992). Self-Efficacy: a theoretical analysis of its determinants and malleability. Academy of Management Review, 17(2), 183-211.

Gray, F. E. (2010). Specific oral communication skills desired in new accountancy graduates. Business Communication Quarterly, 73(1), 40-67.

Guba, E. G. \& Lincoln, Y. S. (1994). Competing paradigms in qualitative research. In: Denzin, N. K. and Lincoln Y. S. eds. Handbook of qualitative research. London: SAGE Publications, 105-117.

Hart, K. E. \& Kritsonis, W. L. (2006). Critical analysis of an original writing on social learning theory: imitation of film-mediated aggressive models by: Albert Bandura, Dorothea Ross and Sheila A. Ross (1963). National Forum of Applied Educational Research Journal, 20(3), 1-7.

International Federation of Accountants. (2008a). International education standard 3: professional skills and general education. New York, USA: International Accounting Education Standards Board.

International Federation of Accountants. (2008b). International education standards 1-8. New York, USA: International Accounting Education Standards Board.

Kerby, D. \& Romine, J. (2009). Develop oral presentation skills through accounting curriculum design and course-embedded assessment. Education for Business, 85(3), 172-179.

Krathwohl, D. (2002). A revision of Bloom's taxonomy: an overview. Theory into Practise, 41(4), 212-225.

Kurland, D. J. (2000). What is critical thinking? Available: http://www.criticalreading.com/critical_thinking.htm (Accessed 29 September 2018).

Mayer, R. E. (2002). Rote versus meaningful Learning. Theory into Practice, 41(4), 226-232.

McLeod, S. A. (2014). Bobo Doll Experiment. Available: https://www.simplypsychology.org/bobo-doll.html (Accessed 06 September 2018).

Naidoo, S. K. \& Garbharran, H. L. (2013). Communication skills as a subject in the programme Cost and Management Accounting at a South African university. Economics and Behavioral Studies, 5(7), 484495.

National education evaluation and development unit. (2013). NEEDU National Report 2012: The State of Literacy Teaching and Learning in the Foundation Phase. Pretoria: National Education Evaluation and Development Unit.

Nel, N. \& Muller, H. (2010). The impact of teachers' limited English proficiency on English second language learners in South African schools. Education, 30, 635-650.

Ormrod, J. E. (2008). Human learning. $5^{\text {th }}$ ed. Upper Saddle River, New Jersey: Pearson Education.

Pickworth, G. (2001). Developing an instrument to identify MBCHB learners' approaches to learning. Higher Education, 15(2), 140-145.

Ramos, J. T. (2010). A study on schema activation, summarizing, and critical evaluation as predictors of writing proficiency. Research and Review, 5(1), 31-39.

Slabbert, J. A. \& Gouws, D. G. (2006).The quest for powerful learning environments in higher education. Higher Education, 20(2), 336-351.

South African Institute of Chartered Accountants. (2008b). The financial management, accounting and auditing skills shortage research report: executive summary. Kengray: SAICA.

Taylor, N., Van der Berg, S. \& Mabogoane, T. (2012). What makes schools effective? Report of the national schools effectiveness study. Cape Town: Pearson Education South Africa.

Thomas, T. (2011). Developing first year learners' critical thinking skills. Asian Social Science, 7(4), 26-35.

Wessels, P. L. (2005). Critical information and communication technology and communication for professional accountants. Meditari Accountancy Research, 13(1), 87-103.

Zimmerman, B. J. (2000). Self-efficacy: an essential motive to learn. Contemporary Educational Psychology, 25, 82-91. 